Financial Statistical Journal (2018) Volume 1 doi:10.24294/fsj.v1i4.1057

\title{
Insurance Development and Economic Growth
}

HuiShan Lee, Zhen-Jiang YONG, Qiao-Ming LIM

Universiti Tunku Abdul Rahman, Malaysia

\begin{abstract}
This study aims to investigate the effect of continent and initial GDP per capita level of a country on the relationship between insurance activities and economic growth. This study considers panel data consists of 123 countries from 1967 to 2014. Both static panel model and dynamic panel model are used to evaluate the effect of both continent and initial GDP per capita level of a country to the economic growth. The findings show significant causal relationship between insurance development and economic growth. However, the relationship is varied in different countries due to different initial income levels and locations. The effect of insurance development on economic growth of a country is indirect because it depends on the performance of the investment of insurers. Therefore, policymakers should consider their own country's special characteristics when formulating a policy. Policymakers should clearly understand the nature of their insurance sector such as interconnectedness between financial sector and insurance sector, whether to promote insurance sector to grow their economy. By understanding the effect of continent and the initial GDP per capita level, policymakers could formulate and implement more effective policies on their country's insurance sector to ensure the prosperity of the country's economic growth.
\end{abstract}

Keywords: Insurance Development; Economic Growth; Regional Analysis; Life Insurance; Non-life Insurance

\section{Introduction}

For decades, the insurance sector has been growing steadily. In 1980, the total premiums accounted for $0.8 \%$ for emerging markets while $5.2 \%$ for advanced markets. In 2015 , both percentage rose to $2.9 \%$ and $8.1 \%$ for emerging markets and advanced markets respectively (Swiss Re, 2017). Insurer compensates insured whenever the insured is harmed or experienced losses while the insured paying the insurance premiums. The insurers, in turn, accumulate new capital (insurance premiums) and invest for the purpose of eventual repayment of claims (Concha, 2014). Insurance sector identifies and measures risks levels, discerns the costs of riskier activities and the efficiency of resources allocation to enhance productivity and risk-coverage (Skiper, 1997). By acting as a provider of risk transfer and institutional investor, insurance activities promote financial stability, mitigate financial losses and transfer domestic savings into investment efficiently (Marco Arena, 2008).

African countries' real GDP growth grows steadily in parallel with the insurance growth since 2000. However, Africa takes a hit when the Global Financial Crisis happens and their real GDP growth slows down, but remains positive. Compares to Africa, the growth in Asian insurance sector starts earlier than 1980. During Asian Financial Crisis 1997, both insurance growth and real GDP growth have slowed down. The Global Financial Crisis 2008 affects Real GDP growth in Asian countries, but not the insurance growth. After 2010, the life insurance growth in Asia fluctuates while non-life insurance growth stagnates and the real GDP growth remains steady at 5\%. For Europe, insurance growth and real GDP growth are mostly aligned to each other. The decrease in insurance growth since 1988 until 1990 causes the real GDP growth slowdown in 1992. In 2001, the growth in both categories drops properly due to dotcom bubble burst and 911 terrorist attack, but the non-life insurance growth is against the trend as it continues to grow. For 2008 - 2009, both growth slow down because of Global Financial Crisis and the European Debt Crisis. The findings on Latin America or South America are surprisingly different from other regions. The insurance does not grow significantly until 2003 unlike other regions. The significant drop in real GDP during 1980s is probably due to the Falklands War and Latin American debt crisis. In 2001, the region's real GDP growth slows down again due to the

EnPress Publisher LLC.This work is licensed under the Creative Commons Attribution-NonCommercial 4.0 International License (CC BY-NC 4.0). http://creativecommons.org/licenses/ by/4.0/ 
default on Argentina's sovereign debt. Despite the drop in real GDP growth, the insurance growth in the region remain strong with a one-year stagnancy in growth during the Global Financial Crisis. The real GDP growth in Latin America is almost in all-time fluctuating since 1980. In North America, which houses the world largest economy - United States of America, has seen a rapid growth both real GDP and insurance after 1982. The real GDP growth drops in 1982 and the life insurance drops in 1983 as well, but the life insurance continues its growth until 1986. The similar trend happens in 2001 when the real GDP growth and life insurance experience slowdown because of the 911 terrorist attack and dotcom bubble burst, the non-life insurance continues to grow. The Global Financial Crisis causes the regional real GDP growth and life insurance growth dropped, the growth rate of non-life insurance remains stagnant. Hence, it can be seen that geographical factor affects the relationship between insurance growth and economic growth.

The impacts of Global Financial Crisis on different regions are disparate. For Africa, Latin America and Asia, the insurance growth does not get affected negatively (grows or remains stagnant) despite the crisis causes the economic growth to slow down. In Europe and North American, the crisis slows down the growth of the life insurance but not the non-life insurance. Interestingly, the Africa, Latin America and Asia are largely constituted by low to medium income level countries, meanwhile most countries in Europe and North America are high-level income countries. Additionally, the characteristics of the growth in Latin America is different from the growth in Africa. The insurance growth in Africa are mainly contributed by the growth of non-life insurance, while the insurance growth in Latin America is mostly contributed by the growth of life insurance. Latin America's case stands out from the rest because there is no relationship between insurance growth and economic growth.

The advancement of technology (information system) changes the landscape of the insurance sector with the introduction of InsurTech. InsurTech provides new insurance models to meet changing customer needs. It provides insurance service through usage-based model and pay as you go pricing model or personalized insurance solution to the e-commerce business and SMEs. So that they can afford the insurance to cover their losses and export in a lower cost. The SMEs is the backbone for economic growth especially in developing countries. This fact is essentially true for the countries in one of the fastest developing region in the world - Association of Southeast Asian Nations (ASEAN). SMEs contribute to $35.9 \%$ of Malaysia's GDP and the share of SMEs to total business in Malaysia is more than 98\%. In 2015, 99.9\% of business in Indonesia are SME. These SMEs contribute 57.9\% to the Indonesian GDP and support 97.2\% of employment. For Thailand, SMEs contribute 39.6\% GDP to the GDP in 2014. Therefore, easier access to insurance for SMEs because of the rise of InsurTech helps to promote the economic growth of a country. Moreover, PwC InsurTech Report mentions about the rising InsurTech offers opportunities for new entrants because new start-ups are able to start from a clean state and provide seamless customer experience. Thus, it could promote both the insurance growth and economic growth (PwC, 2016).

The empirical studies on the relationship between insurance sector and economic are more recent and relatively less extensively studied as compared to the relationship between banking, stock markets and economic growth. (Concha and Taborda, 2014 and Arena, 2008). It is necessary to study the interconnection between insurance activity and economic growth substantially while studying impact of financial sector on economic growth of a country. Alternatively, the globalization increases the interdependency between economies especially in a region. The effects of globalization could be illustrated by subprime crisis 2007 which not only affects United States but spreads to Eurozone. It eventually triggers European Debt Crisis 2009 and the Great Depression. Hence, the contagion effect should be taken into account when studying an economic issue because of the increasing interconnectedness between economies due to globalization. Additionally, the location of a country is being considered not only to study the contagion effect but also because of the similar cultures and regional integration such as ASEAN+3, NAFTA and European Union. The unobserved characteristic as stated above might affect the behaviour of investment of insurance sector, insurance activity and economic growth. Enz (2000) shows that the income elasticity due to insurance activity is varying in economies with different maturities. Consequently, the initial economic condition has to be considered as well to study the impact of insurance sector on economic growth, besides location factor. 
This paper examines the possible causal relationship between insurance sector and economic growth. The other specific objectives are (i) to understand the correlation between economic growth, insurance activity and continents (Asia and Oceania, North America, South America, Africa and Europe), (ii) to evaluate the impact of a country's initial income per capita level on the relationship between insurance activity and economic growth in different continent, (iii) to assess the impact of life insurance and nonlife insurance. This study adds to literature by investigating the interrelationship between the types of insurance, life insurance and nonlife insurance, continent factors, income groups and economic growth. This study bridges the gap by considering insurance activity and economic growth with location of a nation as one of variables in the model. It also provides understanding on the effect of initial income level of a nation in different continent on the impact of insurance activity on economic growth. By understanding the contagion effect, the importance of a location and the initial income level of a nation, the policymakers could sketch and implement a policy that is tailor-made to their nation to promote economic growth.

\section{Literature Review}

Arena (2008) finds that the insurance activity across 55 countries has positive impacts on economic growth, both in terms of jointly or individually (life or non-life insurance). Concha and Taborda (2014) discover that all measures of insurance density, total insurance, life insurance and non-life insurance are positive and highly significant in 11 Latin America countries. Abdul and Nicholas (2016) learn that the positive effect of non-life insurance activity is more prominent in Algeria, Gabon, Kenya, Madagascar, Morocco, and Nigeria while the positive effect of life insurance is more prominent in Mauritius and South Africa. Liyan Han et al. (2010) also find that insurance density, life insurance density and non-life insurance density impacts economic growth positively. Kok, Mori and Fumitakas (2010) show that the Malaysian economic growth and life insurance activity are cointegrating and the long-run relationship between the total assets of Malaysian life insurance is positively significantly to the real GDP of Malaysia. Chen et al. (2012) find robust evidence that the development of the life insurance market has positive impact on economic growth. Su, Chang and Pan (N.A.) find that life insurance development drives the economy of Saudi Arabia, United Arab Emirates, Kuwait and Israel, while non-life insurance development in Saudi Arabia, United Arab Emirates, Oman, and Jordan is driven by their economies.

In Ward and Zurbruegg's (2000) paper, three OECD countries prove the causal relationship between insurance market and economic growth. There is supply-leading in Canada and Japan in which the development of insurance company leads the economic growth. Italy depicts bidirectional relationship between development of insurance market and economic growth although the relationship is weaker than Canada and Japan. Hou, Cheng and Yu (2012) and Lee et al. (2013) suggest that the increasing of life insurance penetration causes economy to grow. Haiss and Su megi (2008) reveal that insurance activity has positive impacts on the EU-15+ group's economies, while the nonlife insurance positively impacts economic growth of emerging economies of Central and Eastern Europe (CEE+). The researchers also find that insurance sector development has a significant positive impact on both capital accumulation and productivity improvement. Azman-saini and Smith (2010) also finds that the insurance sector development is crucial to promote output growth. Results from Abdul and Nicholas (2016) show that the developments in life insurance market enable the real economic to grow more swiftly compared to non-life market. Pradhan et al (2015) find that the development of insurance market significantly drives the long-run economic growth.

The literatures form 3 different theories on the causality relationship between insurance activity and economic growth. The theories are supply-leading hypothesis, demand-following hypothesis and bidirectional feedback hypothesis. Abdul and Nicholas (2016) find that in Algeria, Gabon, Kenya, Madagascar, Mauritius, Nigeria and South Africa support the supply-leading hypothesis. The countries have unidirectional causality from insurance penetration to economic growth across all proxies for insurance activities. Kok, Mori Fumitaka (2010) support the demand-leading hypothesis as Malaysian real GDP is unilaterally Granger caused Malaysian life insurance sector. Su, Chang and Pan (N.A.) find that economic in Saudi Arabia, United Arab Emirate, Iran, Kuwait and Israel are following a 
demand-following pattern is significantly Granger cause the life insurance development. In addition, there is a bilateral interaction relationship between life insurance development and economic growth in these countries. There is supply-leading pattern in Oman and Jordan while there is bidirectional relationship between non-life insurance and economic growth in Saudi Arabia and United Arab Emirates. Horng et al. (2012) find long-run relationship between financial development and economic growth and in the short run, economic growth granger causes the insurance demand (demand-following) and financial development Granger causes economic growth (supply-leading) in Taiwan. Lee et al. (2013) find there is bidirectional causalities between life insurance markets and economic growth in both long-run and short-run which supports the feedback theory. Pradhan et al (2015) dismiss the demand-leading theory because they find that economic growth does not Granger-cause insurance market development in the long-run. Instead, their findings support the feedback hypothesis which states that there is bidirectional causality between insurance market development and economic growth.

Most of the literatures support the statement from Enz (2000) that the income elasticity of insurance demand is not constant across countries. The income elasticity of insurance demand follows a function which is called as S-curve. There is low income elasticity at low and high levels of income but high income elasticity at intermediate income levels. Arena (2008) finds life insurance and nonlife insurance would have bigger impact on economic growth at low and middle levels of economic development compared to high level of economic development. Liyan Han et al. (2010) find that insurance development has more significant impact on developing economies compared to developed economies. They also state that the speed of economic growth is diminishing as the historical economic growth is higher. Chen et al. (2012) claims that life insurance affects the countries with different development levels differently. The positive impact of life insurance is more significant in low-income countries (life insurance penetration) than middle-income countries (life insurance density). Outreville (1990) discovers that the income elasticity on the insurance demand in African is much lower than Latin American and Caribbean countries. The results by Lee et al. (2013) find that the insurance market activity has lesser income elasticity at higher level of income. The income elasticity is higher in the middle-income countries which the speeds of development of both insurance market and economic are swifter than those in high-income countries. The significance of the effect of different types of insurance regarding to the level of income of a country varies. Arena (2008) finds the life insurance is significant in high-income countries and both life and non-life insurance are significant in high-income and nonhigh-income countries, although it has more significant effects on high-income countries. While Arena (2008) shows that life insurance is more significant than nonlife insurance, Liyan Han et al. (2010) shows otherwise. Liyan Han et al. (2010) find that the effect of non-life insurance is more significant on economic growth than life insurance.

The literatures also significant country-specific characteristics affect the insurance activity of a country. Chen and Mitsuyoshi (2013) investigate the contribution of life insurance to economic growth through the education investment and indicate that human capital risk (health conditions or lifetimes) affects the return of the education investment of individuals. The results indicate that life insurance does affect the economic growth, but the degree depends on the individuals' rate of time preference and the productivity of human capital accumulation. Chen et al. (2012) show that life insurance in different regions has different effect economic growth. Azman-saini and Smith (2010) suggest that there is strong relationship between legal origins and insurance sector developments. Ward and Zurbruegg's (2000) find that the causal relationships between economic growth and insurance market development are differ across each other because of the country-specific factors or individual heterogeneity such as risk aversion, culture and stringency of the regulatory framework. Chen et al. (2012) find the life insurance and savings are substitutes in the growth progress because the increase in savings rate may diminish the positive effect of life insurance density on economic growth. The researchers find that life insurance and stock market are substitutes because of the negative and significant interaction effect between them. Outreville (1990) discovers that the demand of insurance has significant positive relationship with the financial development.

Most of the studies focus on either country, a particular continent or income group. Concha and Taborda (2014) 
focus on 11 Latin America country, Sum Chang and Pan (N.A) focus on Middle East, Lee et al. (2013) focus on Europe and Abdul and Nicholas focus on Africa while Ward and Zurbruegg (2000) focus on OECD countries which is high-income countries. They do not investigate the possible relationship between different income groups countries and continents. The S-curve hypothesis of Enz (2000) does not consider possible influence of continent such as culture. Chen and Mitsuyoshi (2013), Azman-saini and Smith (2010) and Ward and Zurbruegg (2000) state that culture such as rate of time preference and legal origins affects the impacts of insurance growth on economic growth. Other studies support S-curve hypothesis as well (Luyan Han et al., 2010; Chen et al., 2012). The continent factor should be considered when estimating the effect of insurance growth on economic growth, Outreville (1990) has shown that income elasticities in between African, Latin America and Caribbean are different. Overall, majority studies suggest that life insurance and nonlife insurance contribute differently to the economic growth.

\section{Methodology}

\subsection{Research design}

This study is a quantitative research that uses econometrics analytic techniques to study the relationship of insurances sector's activity towards a country. The data used is a panel data dated from 1967 to 2014 across 123 countries. There are 4 approaches taken by this study:

Non-dynamic Panel Models or Static Model:

\subsubsection{Panel Least Squares}

Pooled least squares is a least squares estimator that applied to a pooled model. The data for different countries will be pooled together and then estimated using least squares. Therefore, pooled least squares has no provision for individual differences or individual heterogeneity. The data is considered as non-random due to large sample properties. The assumptions in this estimation method are:

a. Zero mean, $\mathrm{E}\left(\mathrm{e}_{\mathrm{it}}\right)=0$

b. Homoskedasticity, $\operatorname{var}\left(\mathrm{e}_{\mathrm{it}}\right)=\mathrm{E}\left(\mathrm{e}_{\mathrm{it}}^{2}\right)=\sigma_{\mathrm{e}}^{2}$

c. All errors are uncorrelated, $\operatorname{cov}\left(e_{i t}, e_{j s}\right)=E\left(e_{i t}, e_{j s}\right)=0$ for $i \neq j$ or $t \neq s$ (all errors are uncorrelated)

d. Errors uncorrelated with $x ' s, \operatorname{cov}\left(e_{i t}, x_{i t}\right)=0$ (errors uncorrelated with $x$ 's)

With the assumptions in place, the usual $\mathrm{t}$ and $\mathrm{F}$ statistics are applicable in large samples for hypothesis testing and interval estimation.

In addition, the cluster-robust standard errors will be used instead of the original standard errors because of the presence of the individual heterogeneity. The effects of the individual heterogeneity will be included in the error term under pooled least squares estimation. The variance of the error terms is possibly different in different time period. However, the errors are uncorrelated in between of individual. Therefore. The application of the cluster-robust standard errors will correct the incorrect standard errors while the least squares estimator is still remaining consistent.

\subsubsection{Fixed Effects Model}

Contrary to pooled least squares, the fixed effects model takes in account the individual heterogeneity. In this model, the individual heterogeneity is being captured by the intercept. For example:

$y_{i t}=\beta_{1 i}+\beta_{2} x_{2 i t}+\beta_{3} x_{3 i t}+e_{i t}$

The $\beta_{1 \mathrm{i}}$ is the intercept of the model and the subscript $\mathrm{i}$ denotes the ith individual. Note that the $\beta_{1 \mathrm{i}}$ only capture the individual-specific and time-invariant characteristics. Typically, the dummy variable is one of the technique to allow different intercept for each individual, but the large number of individuals (countries) would make this approach inappropriate because of large number of dummy variables.

Another approach will be taken for the fixed effects model and it is illustrated as below:

$$
\begin{gathered}
y_{i t}=\beta_{1 i}+\beta_{2} x_{2 i t}+\beta_{3} x_{3 i t}+e_{i t} \ldots(1) \\
\bar{y}_{i}=\beta_{1 i}+\beta_{2} \bar{x}_{2 i}+\beta_{3} \bar{x}_{3 i}+\bar{e}_{i} \ldots(2)
\end{gathered}
$$

(2) is the averaged variables over time. By subtracting (2) form (1), the intercept $\beta_{1 \mathrm{i}}$ is eliminated.

$$
\mathrm{y}_{\mathrm{it}}-\overline{\mathrm{y}}_{\mathrm{i}}=\beta_{2}\left(\mathrm{x}_{2 \mathrm{it}}-\overline{\mathrm{x}}_{2 \mathrm{i}}\right)+\beta_{3}\left(\mathrm{x}_{3 \mathrm{it}}-\overline{\mathrm{x}}_{3 \mathrm{i}}\right)+\left(\mathrm{e}_{\mathrm{it}}-\overline{\mathrm{e}}_{\mathrm{i}}\right)
$$


Which can be transformed into

$$
\tilde{y}_{i t}=\beta_{2} \tilde{\mathrm{x}}_{2 i t}+\beta_{3} \tilde{\mathrm{x}}_{3 i t}+\tilde{\mathrm{e}}_{i t} \ldots(3)
$$

In (3), all the variables are in deviation from the mean form. The transformed model only estimates the effects of the variation of the dependent and explanatory variables within individuals, not between individuals.

\subsubsection{Random Effects Model}

In random effects model, the individual heterogeneity is captured in the intercept of the model, similar with fixed effects model. However, the individual heterogeneity is treated as random rather than fixed.

The model is then modified into

$$
y_{i t}=\left(\bar{\beta}_{1}+u_{i}\right)+\beta_{2} x_{2 i t}+\beta_{3} x_{3 i t}+e_{i t}
$$

$$
y_{i t}=\beta_{1 i}+\beta_{2} x_{2 i t}+\beta_{3} x_{3 i t}+v_{i t}
$$

while

$$
v_{i t}=u_{i}+e_{i t}
$$

The error term assumptions for this model are as follow:

a. Zero Mean, $E\left(v_{i t}\right)=0$

b. Homoscedasticity, $\operatorname{var}\left(v_{i t}\right)=\sigma_{e}^{2}+\sigma_{u}^{2}$

c. Errors for individual $i$ are correlated, $\operatorname{cov}\left(v_{i t}, v_{i s}\right)=\sigma_{u}^{2}$ for $t \neq s$

d. Errors for different individuals are uncorrelated, $\operatorname{cov}\left(v_{i t}, v_{j s}\right)=0$ for $i \neq j$

e. Errors $e_{i t}$ uncorrelated with $x$ 's, $\operatorname{cov}\left(e_{i t}, x_{2 i s}\right)=0, \operatorname{cov}\left(e_{i t}, x_{3 i s}\right)=0$

f. Random effects uncorrelated with $x$ 's, $\operatorname{cov}\left(u_{i}, x_{2 i t}\right)=0, \operatorname{cov}\left(u_{i}, x_{3 i t}\right)=0$

Similar to the Pooled Ordinary Least Squares, the Random Effects Model employs cluster-robust standard errors rather than the original standard errors because of the presence of the individual heterogeneity.

Dynamic Model:

Arrelano - Bond First Difference two-step GMM Model

Assume the dynamic model as follow:

$$
y_{i t}=y_{i t-1} \gamma+\mathrm{x}_{i t} \beta+u_{i}+\epsilon_{i t}
$$

While $u_{i}$ is the unobserved individual heterogeneity.

First, first differencing the model equation yields

$$
\Delta y_{i t}=\Delta y_{i t-1} \gamma+\Delta x_{i t} \beta+\Delta \epsilon_{i t}
$$

The $u_{i}$ are eliminated, but the $y_{i t-1}$ in $\Delta y_{i t-1}$ is a function of the $\epsilon_{i t-1}$ which is also in $\Delta \epsilon_{i t}$. Therefore, $\Delta y_{i t-1}$ is endogenous because it is correlated with $\Delta \epsilon_{i t}$ by construction.

Anderson and Hsiao (1981) suggest a 2SLS estimator based on further lags of $\Delta y_{i t}$ as instruments for $\Delta y_{i t-1}$. For instance, if $\epsilon_{i t}$ is i.i.d over $i$ and $t, \Delta y_{i t-2}$ would be a valid instrument for $\Delta y_{i t-1}$.

Holtz-Eakin et al.(1988) and Arellano and Bond (1991) illustrate the formation of moment condition from further lagged levels of $y_{i t}$ and the first-differenced errors which is $E\left(y_{i t-2} \Delta \epsilon_{i t}\right)=0$ by assuming that $y_{i t-2}$ are orthogonal to $\Delta \epsilon_{i t}$.

As the number of moment conditions exceeded the number of parameter, the Generalized Method of Moments framework is used.

By applying the analogy principle, the estimatow $\widehat{\beta}$ chosen should solve the moment condition of the following

$$
N^{-1} \sum \mathrm{Z}_{i}^{\prime}\left(y_{i}-\mathrm{X}_{i} \widehat{\beta}\right)=0
$$

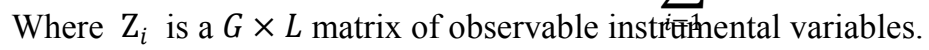

In the situation of having more instrumental variables than estimators, there will be no exact solution. Therefore, the $\widehat{\beta}$ that has the smallest vector or minimum squared Euclidean length in $N^{-1} \sum_{i=1}^{N} \mathrm{Z}_{i}^{\prime}\left(y_{i}-\mathrm{X}_{i} \widehat{\beta}\right)=0$.

Weighting Matrix, $W$ is used and the choice of $W$ is that produces the GMM estimator with the smallest asymptotic variance which is $\widehat{\mathrm{W}} \equiv\left(N^{-1} \sum_{i=1}^{N} \mathrm{Z}_{i}^{\prime} \breve{\mathrm{u}}_{i}^{\prime} \breve{\mathrm{u}}_{i}^{\prime} \mathrm{Z}_{i}\right)^{-1}$

$$
\breve{\mathrm{u}}_{i}=y_{i}-X_{i} \breve{\beta} \text {, the residuals from the initial estimation. }
$$

Then, the estimators $\widehat{\beta}$ are gained from $\widehat{\beta}=\left[\mathrm{X}^{\prime} \mathrm{ZWZ} \mathrm{X}\right]^{-1} X^{\prime} Z W Z^{\prime} Y$. 
This study conducts in three different ways to study three different effects on how insurance and economic growth is related. The three different effects are the effect of continent, initial GDP per capita of a country and different initial income level of a country in different continent on the relationship between insurance and economic growth. Different interaction terms will indicate the effect that is intended to study. Firstly, to study the effect of a country located in Asia on the relationship between life insurance penetration and economic growth, interaction term, asialligdp, will be included to other independent variables in the model which is the interaction between indicator variable, asia (for countries located in Asia), and independent variable, lligdp (life insurance penetration). Secondly, to study the effect of initial GDP per capita of a country on the relationship between life insurance penetration and economic growth, interaction term such as g1lligdp will be included which is the interaction between g1 (one of the categories of initial GDP per capita) and lligdp. Lastly, to study the effect of initial income level of a country in Asia on the relationship between insurance and economic growth, interaction term, asiagllligdp, will be used, which is the interaction between asia, g1 and lligdp. All cases in this study will be estimated with both static panel model (after choosing the most effective model) and dynamic panel model.

\subsection{Data collection methods \& research instrument}

The data was taken from the World Development Indicators of World Bank, Global Financial Development of World Bank and author's calculation. In this study, the dependent variable is the economic growth denoted by gross domestic product (GDP) per capita (gdppc). This variable is converted to international dollars using purchasing power parity (PPP) rates because the international dollar has the same purchasing power over GDP as the U.S. dollar has in the United States. The data are in current international dollars based on the 2011 ICP round. This variable is chosen in consistent with economic growth literature that the dependent variable is the average rate of real capita GDP growth (Marco Arena, 2008). PPP instead of market exchange rate is used since it factors in the role of non-traded goods (Rudolf Enz, 2000).

The explanatory variables of interest are life insurance premium and nonlife insurance premium. The explanatory variables in Equation 1 is insurance premium of volume to GDP (\%) or insurance penetration. For the Equation 2, the explanatory variable is the insurance density rate which is measured by the insurance premium volume per capita. The first equation is insurance penetration expresses in terms of volume to GDP (\%) are extracted from Global Financial Development of World Bank and it contains two variables which are life insurance premium volume to GDP (\%) and nonlife insurance premium volume to GDP (\%). The second equation is insurance density, shows the insurance premium per capita.

\section{Life Insurance Density}

$$
=(\text { Life insurance premium volume to GDP }(\%) \times G D P(\text { current US\$) }) /(\text { Population, total })
$$

Nonlife Insurance Density = (Nonlife insurance premium volume to GDP $(\%) \times G D P($ current US\$))/ (Population, total)

There are 7 other independent variables involved in both equations:

a. Trade as \% of GDP (trade) is the sum of external trade of goods and services as percentage of gross domestic product. Hou H. et al. (2012) state that trade is a standard information for economic growth. The relationship between trade and economic growth is expected to be positive.

b. Education (educ) is derived as the ratio of total gross enrolment into tertiary education to the population. It represents the human capital in respective countries. The expectation of the relationship between education and economic growth is positive.

c. Real interest rate (\%) (rir) is the lending interest rate after the adjustment for inflation by the GDP deflator. The expected relation between economic growth is negative.

d. Total stock traded value as \% of GDP (stock) acts as a proxy for stock market development and its relationship with economic growth is expected to be positive.

e. Inflation (inf) is the consumer price index which shows the annual percentage change in the cost to average 
consumer of acquiring a basket of goods and services. The relationship between inflation and economic growth is positive.

f. Domestic credit to private sector by banks (\% of GDP) (bank) refers to financial resources provided to the private sector by other depository corporations (except central bank) such as loans, purchases of non-equity securities, trade credits and other accounts receivable that establish a claim for repayment. For some countries, these claims include credit to public enterprises. Its relationship with economic growth is expected to be positive.

g. Foreign direct investment (fdi) is the foreign capital inflow into domestic economy which would influences the growth of the economy. In this study, this variable has been transformed into percentage of foreign direct investment to GDP, $f d i($ variable $)=($ Foreign Direct Investment $) / G D P$. The expected relationship of this variable and economic growth is positive.

There are also several indicator variables to show the individual characteristics of the countries. The g1, g2, g3 indicator variables indicate the initial GDP per capital of the countries.

$\mathrm{g} 1=\{\boldsymbol{\square}(1$, if the initial GDP of the country is above the 66th percentile @0, if others)-

$g 2=\{\mathbf{\square}(1$, if the initial GDP of the country is between 33rd and 66th percentile @0, if others)$g 1=\{\mathbf{\square}(1$, if the initial GDP of the country is below 33th percentile @0, if others)

While the asiaocea, europe, northamerica, southamerica and Africa indicate the country's continent.

$$
\begin{aligned}
& \text { asiaocea }=\{(1, \text { if the country is in Asia or Oceania @0, if others }) \dashv \\
& \text { europe }=\{\boldsymbol{\square}(1, \text { if the country is in Europe @0, if others }) \dashv \\
& \text { northamerica }=\{\mathbf{\square}(1, \text { if the country is in North America @0, if others }) \dashv \\
& \text { southamerica }=\{\mathbf{\square}(1, \text { if the country is in South America @0, if others }) \dashv \\
& \text { africa }=\{\mathbf{\square}(1, \text { if the country is in Africa @0, if others }) \dashv
\end{aligned}
$$

\subsection{Data processing}

Most of the variables have undergone logarithm and cube root transformations before being used in estimation. Both transformations aim to decrease the severity of heteroskedasticity that might present in estimations. Logarithm transformation is the first choice because it has significant effect on the distribution shape. However, this transformation cannot be applied to zero and negative values. Alternatively, the cube root is used despite it has weaker influence than the logarithm transformation (Nicholas J. Cox, 1999). The transformed variables will be used in all estimations covered in this study. Furthermore, different countries are being assigned by a unique code to represent a distinct country. For example: Malaysia's unique code is 101 and France's unique code is 203. The first digit represents the geographical location of the country in term of continent. 1, 2, 3, 4, 5 represent Asia and Oceania continents, Europe continents, North America, South America and Africa continent respectively. Table 1 shows the final variable and the symbols of the variables in the model.

\begin{tabular}{|l|l|}
\hline Dependent Variables & lgdppc \\
\hline GDP per capita (in logarithm form) & \multicolumn{2}{l|}{} \\
\hline \multicolumn{2}{|l|}{} \\
\hline Independent Variables & lligdp \\
\hline Life Insurance penetration (in logarithm form) & lnligdp \\
\hline Nonlife Insurance penetration (in logarithm form) & llid \\
\hline Life Insurance density (in logarithm form) & lnlid \\
\hline Nonlife Insurance Density (in logarithm form) & ltrade \\
\hline Trade as \% of GDP (in logarithm form) & educ \\
\hline Education & rir \\
\hline Real Interest Rate & infcr \\
\hline Inflation (in cube root form) & fdicr \\
\hline Foreign Direct Investment (net inflow) (in cube root form) & \\
\hline
\end{tabular}




\begin{tabular}{|l|l|}
\hline Total stock traded value as \% of GDP (in cube root form) & stockcr \\
\hline Domestic credit to private sector by banks (\% of GDP) (in logarithm form) & lbank \\
\hline Indicator Variables & $\mathrm{g} 1$ \\
\hline Country's initial GDP is below $66^{\text {th }}$ percentile & $\mathrm{g} 2$ \\
\hline Country's initial GDP is in between $66^{\text {th }}$ and $33^{\text {rd }}$ percentile & $\mathrm{g} 3$ \\
\hline Country's initial GDP is after $66^{\text {th }}$ percentile & asiaocea \\
\hline Country from Asia or Oceania & europe \\
\hline Country from Europe & northamerica \\
\hline Country from North America & southamerica \\
\hline Country from South America & africa \\
\hline Country from Africa & \\
\hline
\end{tabular}

Table 1. Dependent variables and independent variables

\subsection{Data analysis}

Stata version 13.0, a data analysis and statistical software developed by StataCorp was used in this study. The panel data is unbalanced due to the missing values in the observations. Table 2 and Table 3 show the correlation and multicollinearity between variables. Both groups show low multicollinearity between explanatory variables albeit group 2 has higher multicollinearity as compared to group 1 for Variance Inflator Factor test.

\begin{tabular}{|c|c|c|c|c|c|c|c|c|c|c|c|c|c|c|c|c|c|c|c|c|}
\hline & $\begin{array}{l}\text { lgd } \\
\text { ppc }\end{array}$ & $\begin{array}{l}\text { llig } \\
\text { dp }\end{array}$ & $\begin{array}{l}\text { Inli } \\
\text { gdp }\end{array}$ & Ilid & $\begin{array}{l}\text { Inli } \\
\text { d }\end{array}$ & $\begin{array}{l}\text { Itra } \\
\text { de }\end{array}$ & $\begin{array}{l}\text { edu } \\
\text { c }\end{array}$ & rir & $\begin{array}{l}\text { infc } \\
r\end{array}$ & $\begin{array}{l}\text { fdic } \\
\mathbf{r}\end{array}$ & $\begin{array}{l}\text { stoc } \\
\text { ker }\end{array}$ & $\begin{array}{l}\text { lba } \\
\text { nk }\end{array}$ & g1 & g2 & g3 & $\begin{array}{l}\text { asi } \\
\text { a }\end{array}$ & $\begin{array}{l}\text { eur } \\
\text { ope }\end{array}$ & $\begin{array}{l}\text { nort } \\
\text { h } \sim \text { a }\end{array}$ & $\begin{array}{l}\text { sour } \\
\text { th } \sim \text { a }\end{array}$ & $\begin{array}{l}\text { afr } \\
\text { ica }\end{array}$ \\
\hline $\begin{array}{l}\text { lgd } \\
\text { ppc }\end{array}$ & $\begin{array}{l}1.0 \\
000\end{array}$ & & & & & & & & & & & & & & & & & & & \\
\hline $\begin{array}{l}\text { llip } \\
\text { dp }\end{array}$ & $\begin{array}{l}0.5 \\
283\end{array}$ & $\begin{array}{l}1.0 \\
000\end{array}$ & & & & & & & & & & & & & & & & & & \\
\hline $\begin{array}{l}\text { Inli } \\
\text { gdp }\end{array}$ & $\begin{array}{l}0.6 \\
083\end{array}$ & $\begin{array}{l}0.4 \\
995\end{array}$ & $\begin{array}{l}1.0 \\
000\end{array}$ & & & & & & & & & & & & & & & & & \\
\hline llid & $\begin{array}{l}0.8 \\
394\end{array}$ & $\begin{array}{l}0.8 \\
903\end{array}$ & $\begin{array}{l}0.6 \\
400\end{array}$ & $\begin{array}{l}1.0 \\
000\end{array}$ & & & & & & & & & & & & & & & & \\
\hline $\begin{array}{l}\text { Inli } \\
\text { d }\end{array}$ & $\begin{array}{l}0.9 \\
248\end{array}$ & $\begin{array}{l}0.6 \\
025\end{array}$ & $\begin{array}{l}0.8 \\
285\end{array}$ & $\begin{array}{l}0.8 \\
778\end{array}$ & $\begin{array}{l}1.0 \\
000\end{array}$ & & & & & & & & & & & & & & & \\
\hline $\begin{array}{l}\text { Itra } \\
\text { de }\end{array}$ & $\begin{array}{l}0.2 \\
343\end{array}$ & $\begin{array}{l}0.1 \\
652\end{array}$ & $\begin{array}{l}0.2 \\
015\end{array}$ & $\begin{array}{l}0.1 \\
718\end{array}$ & $\begin{array}{l}0.1 \\
750\end{array}$ & $\begin{array}{l}1.0 \\
000\end{array}$ & & & & & & & & & & & & & & \\
\hline $\begin{array}{l}\text { edu } \\
\text { c }\end{array}$ & $\begin{array}{l}0.7 \\
010\end{array}$ & $\begin{array}{l}0.4 \\
050\end{array}$ & $\begin{array}{l}0.5 \\
383\end{array}$ & $\begin{array}{l}0.6 \\
266\end{array}$ & $\begin{array}{l}0.7 \\
131\end{array}$ & $\begin{array}{l}0.0 \\
469\end{array}$ & $\begin{array}{l}1.0 \\
000\end{array}$ & & & & & & & & & & & & & \\
\hline rir & $\begin{array}{l}-0.2 \\
369\end{array}$ & $\begin{array}{l}-0.1 \\
916\end{array}$ & $\begin{array}{l}-0.0 \\
442\end{array}$ & $\begin{array}{l}-0.2 \\
233\end{array}$ & $\begin{array}{l}-0.1 \\
655\end{array}$ & $\begin{array}{l}-0.2 \\
369\end{array}$ & $\begin{array}{l}-0.1 \\
667\end{array}$ & $\begin{array}{l}1.0 \\
000\end{array}$ & & & & & & & & & & & & \\
\hline $\begin{array}{l}\text { infec } \\
r\end{array}$ & $\begin{array}{l}-0.4 \\
535\end{array}$ & $\begin{array}{l}-0.5 \\
012\end{array}$ & $\begin{array}{l}-0.2 \\
361\end{array}$ & $\begin{array}{l}-0.5 \\
524\end{array}$ & $\begin{array}{c}-0.4 \\
353\end{array}$ & $\begin{array}{l}-0.1 \\
449\end{array}$ & $\begin{array}{l}-0.3 \\
830\end{array}$ & $\begin{array}{l}0.1 \\
318\end{array}$ & $\begin{array}{l}1.0 \\
000\end{array}$ & & & & & & & & & & & \\
\hline $\begin{array}{l}\text { fdic } \\
\mathbf{r}\end{array}$ & $\begin{array}{l}-0.0 \\
682\end{array}$ & $\begin{array}{l}0.1 \\
747\end{array}$ & $\begin{array}{l}-0.2 \\
292\end{array}$ & $\begin{array}{l}0.0 \\
328\end{array}$ & $\begin{array}{l}-0.1 \\
698\end{array}$ & $\begin{array}{l}0.0 \\
339\end{array}$ & $\begin{array}{l}-0.0 \\
277\end{array}$ & $\begin{array}{l}-0.1 \\
824\end{array}$ & $\begin{array}{l}-0.0 \\
413\end{array}$ & $\begin{array}{l}1.0 \\
000\end{array}$ & & & & & & & & & & \\
\hline $\begin{array}{l}\text { stoc } \\
\text { ker }\end{array}$ & $\begin{array}{l}0.5 \\
407\end{array}$ & $\begin{array}{l}0.6 \\
026\end{array}$ & $\begin{array}{l}0.2 \\
277\end{array}$ & $\begin{array}{l}0.6 \\
347\end{array}$ & $\begin{array}{l}0.4 \\
644\end{array}$ & $\begin{array}{l}0.0 \\
496\end{array}$ & $\begin{array}{l}0.4 \\
359\end{array}$ & $\begin{array}{l}-0.2 \\
143\end{array}$ & $\begin{array}{c}-0.3 \\
758\end{array}$ & $\begin{array}{l}0.4 \\
223\end{array}$ & $\begin{array}{l}1.0 \\
000\end{array}$ & & & & & & & & & \\
\hline $\begin{array}{l}\text { lba } \\
\text { nk }\end{array}$ & $\begin{array}{l}0.5 \\
242\end{array}$ & $\begin{array}{l}0.5 \\
991\end{array}$ & $\begin{array}{l}0.4 \\
172\end{array}$ & $\begin{array}{l}0.6 \\
283\end{array}$ & $\begin{array}{l}0.5 \\
276\end{array}$ & $\begin{array}{l}0.3 \\
290\end{array}$ & $\begin{array}{l}0.3 \\
586\end{array}$ & $\begin{array}{l}-0.1 \\
799\end{array}$ & $\begin{array}{l}-0.4 \\
472\end{array}$ & $\begin{array}{l}0.3 \\
143\end{array}$ & $\begin{array}{l}0.5 \\
361\end{array}$ & $\begin{array}{l}1.0 \\
000\end{array}$ & & & & & & & & \\
\hline g1 & $\begin{array}{l}-0.6 \\
853\end{array}$ & $\begin{array}{l}-0.2 \\
116\end{array}$ & $\begin{array}{l}-0.6 \\
117\end{array}$ & $\begin{array}{l}0.4 \\
909\end{array}$ & $\begin{array}{l}-0.7 \\
059\end{array}$ & $\begin{array}{l}-0.2 \\
339\end{array}$ & $\begin{array}{l}-0.4 \\
830\end{array}$ & $\begin{array}{l}-0.0 \\
152\end{array}$ & $\begin{array}{l}0.1 \\
683\end{array}$ & $\begin{array}{l}0.3 \\
752\end{array}$ & $\begin{array}{l}-0.1 \\
585\end{array}$ & $\begin{array}{l}-0.2 \\
378\end{array}$ & $\begin{array}{l}1.0 \\
000\end{array}$ & & & & & & & \\
\hline
\end{tabular}




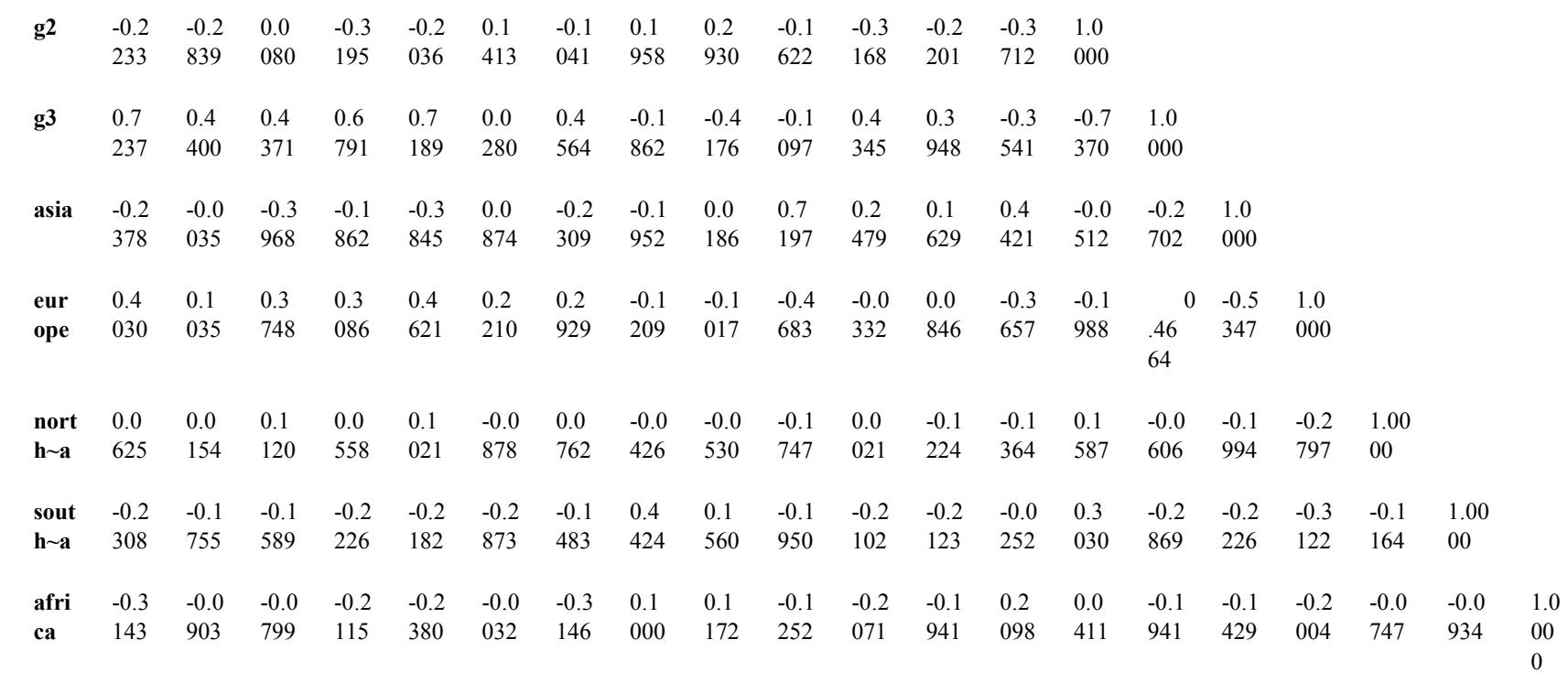

Table 3. Correlation between variables (corr lgdppc \$v1list lligdp lnligdp)

\begin{tabular}{|l|l|l|l|l|}
\hline & Equation 1 & & Equation 2 & \\
\hline Variable & VIF & 1/VIF & VIF & 1/VIF \\
\hline lligdp & 2.23 & 0.449287 & 7.37 & 0.135603 \\
\hline lbank & 2.20 & 0.455418 & 7.16 & 0.139608 \\
\hline stockcr & 2.12 & 0.471871 & 2.39 & 0.418199 \\
\hline lnligdp & 2.12 & 0.472147 & 2.24 & 0.446119 \\
\hline educ & 1.78 & 0.560745 & 2.22 & 0.449627 \\
\hline fdicr & 1.60 & 0.624062 & 1.82 & 0.550769 \\
\hline infcr & 1.52 & 0.660041 & 1.54 & 0.647881 \\
\hline ltrade & 1.24 & 0.808323 & 1.23 & 0.816218 \\
\hline rir & 1.14 & 0.877367 & 1.15 & 0.869760 \\
\hline Mean VIF & 1.77 & & 3.01 & \\
\hline
\end{tabular}

Table 4. Multicollinearity between explanatory variables

\section{Data Analysis}

\subsection{The effect of continent / regional factor}

Both static models and dynamic model (difference GMM model) show that insurance density for life and nonlife promotes economic growth. For insurance penetration, the results are varied. While most of the static models show that life insurance penetration is positively significant to economic growth, but GMM shows contradicting result. Most of the models does not show there is significant relationship between nonlife insurance penetration and economic growth, albeit all coefficients are negative. For regional factors, most results show that the positive effect of insurance development is amplified in Asia while the positive effect of life insurance development is much significant in Africa. Contrary, the positive effect of insurance development is mitigated in Europe and South America. Generally, the relationship between economic growth and insurance development is not significant in North America. Exceptionally, the relationship between life insurance density and economic growth are significantly positive at $10 \%$ significance level. Different economic prospects and distinguished structural and economic policies in different regions are possible reasons for the different effect of different region on its economic growth.

Firstly, the insurance development has less contribution on Europe's economic growth in is possibly due to prolonged ultra-low interest rate in Euro Zone and high interconnectedness between insurers and banks and economic 
issues in Europe. In Europe, expansionary monetary policy has been implemented to stimulate business activities after Global Financial Crisis 2008 and European Debt Crisis 2009. The key European Central Bank (ECB) interest rates has maintained lower than $2 \%$ since 2009 and $0 \%$ since 2016. However, the prolonged ultra-low interest rate would negatively impact the return of insurers especially European life insurer that provides minimum guarantee products. German life insurers increase their share of corporate bonds which offer a higher return but at higher risk. Some large insurers in Belgium are currently facing net cash outflows on their portfolio due to high lapse rate.

Next, the high interconnectedness between insurers and banks and insurers and sovereign in Europe has mitigated the positive effect of the insurance growth from insurance development. This high interconnectedness would increase the market risk, default risk and liquidity. Insurers and banks are highly interconnected because more than half of total assets in euro financial sector held by euro area insurers. As of Q4 2014 for euro area and Q3 2013 for Sweden, the insurers from these two areas have largest exposure to other financial institution (investment fund). As Nyholm (2012) concludes that insurance companies and banks in Europe are highly interconnected and both are equally systemically important. This shows that the channel of European insurers to contribute to economic growth is through the investments on banks. However, European banks are still bearing liquidity problems since European debt crisis 2009 with 1.2 trillion euros worth non-performing loans (NPLs) at 2016 (NPLs to total loan are 5\% for Deutsche banks, 18\% for Italian banks, $12 \%$ for Portuguese banks and 9.8\% for Spanish banks respectively). Furthermore, the profitability of European banking system is shrinking and affecting financial stability in Europe. It may slow the recovery of European banks after Global Financial Crisis 2008.

European insurers are also highly interconnected with European sovereign states. As of Q4 2014 for Europe and Q3 2013 for Sweden, the insurers have second largest exposure to government (sovereign). The systemic risk is higher when the link between insurers and their home sovereign is stronger and the link between insurers and their counterparties outside Europe is weaker by comparing 2008 and 2013 data. German insurers not only invest in their home sovereign bonds but also Italian and Spanish sovereign papers. This implies that European insurers also contribute to economic growth through the investments on governments. However, the sovereign states in Europe are facing debt problem with more than 100\% of sovereign debt as percentage of GDP in 2015 - Belgium (105.8\%), Greece (177.4\%), Italy (132.2\%), Cyprus (107.5\%) and Portugal (129\%). The largest economies in Euro zone also have high sovereign debt as percentage of GDP like Germany (71.2\%), Spain (99.8\%), France (96.2\%) and United Kingdom (89.1\%). A total of 21 European countries violate the $60 \%$ of debt to GDP percentage limit in the Maastricht Treaty. Therefore, the prolonged interest rate reduces the European insurers' investment. European banking sectors problem and sovereign debt problems also reduce the efficiency of putting investment from insurers into economy.

Secondly, South America drives their economies mainly through the commodity export. Latin America (South America and Central America) has seen an increase of $20 \%$ of commodity export in a decade, from $40 \%$ (1994) to 60\% (2014). However, lower demand for commodity from China affects the economic health and insurance markets of the region. IMF data shows that South America's real GDP growth is decreasing since 2010. Alternatively, insurers prefer stable and predictable economic environment whenever taking long-term risk investments. However, high inflation and devaluation of currencies in South America reduce the returns for insurer. The average inflation from 2010 to 2014 for Colombia, Brazil, Argentina and Chile are 3.4\%, 7.2\%, 20.5\% and 4\% respectively and the average currency devaluation from 2010 to 2014 for Colombia, Brazil, Argentina and Chile are 10\%, 14\%, 23\% and 6\% respectively. Similarly, the appreciation of USD against South American currencies increase the governments' debt burden since these countries have large amounts of USD denominated debt.

The social perspective of South America suggests that there is a high degree of income inequality. It lacks of suitably products that is specifically tailored for the poor. In Brazil, more than $70 \%$ of drivers only have compulsory third-party limited minimum coverage they receive with their road tax payment. South America countries such as Argentina and Brazil practice protectionist policy to protect their insurance sector from international competition. In Argentina, only local insurers are allowed to offer insurance on imported and exported goods. After 1994, foreign 
insurers are permitted to provide such insurance cover but those insurers are considered as non-admitted foreign insurers. Non-admitted insurer is considered riskier because they are not regulated and thus there is no guarantee for the policyholder whenever insurer declares bankruptcy. This increases the insurance cost and insurance for catastrophic risks would be prohibitively difficult due to limited risk pooling across national borders. In brief, insurance development does not contribute much to South America's economic growth probably due to the economic instability, high income inequality and protectionism against insurance sector. The economic instability reduces the insurers' profit and insurers are unwillingly to reinvest their profit. Large poor population can't afford insurance and they might have to reduce their consumption to save for any anticipation of unfortunate events. Possible high insurance cost due to protectionist policy might deter the locals from buying insurance. Local have to pay for higher insurance cost and eventually reduce their consumption which in turn deteriorate the economic growth.

Contrary to the practice in South America, Asian countries such as China and India are liberalizing their insurance markets. There are more than 50 applications to set up mutual insurance companies in China whenever the liberalization in India causes a series of merger and acquisition (M\&A) and encourages entry of international insurers such as Swiss Re and Munich Re. Intensified competition makes insurance to be more affordable for the locals. The economic growth in Asia is strong with an average of 8.2\% growth rate from 2002 to 2011. The growth rates estimated from 2012 to 2015 are all above 6\% which are significantly higher than other regions, albeit the economic slowdown in China. In 2014, Asia's real economic growth is $6.3 \%$ while global real economic growth is mere $2.5 \%$. In fact, Asia contributes to $55 \%$ of global economic growth. In parallel with Asian strong economic growth, Asian insurance markets are also among the fastest-growing insurance markets. There are insurers who are able to benefit in some Asian countries during Global Financial Crisis 2008. One of them is Malaysia, which the capital market and demand for unit-linked life insurance has experienced swift recovery. Demand of insurance in Thailand and Philippines are also increase during the financial crisis due to the state-run programs that aim to improve financial literacy.

Africa is one of the world's fastest growing regions besides Asia. IMF data shows that African real GDP growth declines from more than 5.5\% during 2003-2008 to around 3.5\% in recent years because of lower export demand and lower commodity prices. Yet, the region still has relatively high growth compared to other regions except Asia. The growth is due to advancement of productivity in agriculture, growing urban markets, larger high-value exports, undergoing giant infrastructure projects and higher technology penetration that enhances activities of trade and commerce. In addition, Africa experiences rapid urbanization and increasing consumer demand due to population boom and rise of middle-income class. It allows Chana and Zambia moved from low-income country into middle-income country. Sub-Saharan Africa has the fastest FDI growing region in the world. However, the large inflow of FDI in Africa also signifies financial risks because it might due to pro-cyclical flow and private investors only focus on maximising their capital gains. To sustain Africa's economic growth and financial stability, low cost and low risk financial sources such as local household savings is required. Life insurance market can channel household savings into long-term domestic investment by accumulating insurance premium received from selling long-term saving products and then invest into domestic market. Life insurance focus on long-term stable income since the savings have long-term maturities.

The development of life insurance sector also eases African governments' social burden. Economic benefit of life insurance is important in expanding middle-income class because these people are able to afford the insurance but still vulnerable to economic shocks. The long-term investment is utmost for Africa as Africa is still underdeveloped. The positive outlook of Africa also attracts life insurers to have long-term investment. Life insurance also increase the financial durability of the African so that they would not be hampered by economic shock. Therefore, it explains why the life insurance plays a more significant role than nonlife insurance in economic growth of Africa.

\subsection{Initial GDP per capita of a country as a factor}

Similar to the results from last section, the results also show that the effect of insurance development on economic varies according to initial GDP per capita of a country too. Static models show that life insurance and nonlife insurance (except nonlife insurance penetration which is insignificant) promote economic growth in g1 countries more than g3 
countries but have no effect on g2 countries. The outcome supports the findings from Arena (2008), Liyan Han et al. (2010) and Chen et al. that economy grows slower as the historical economic growth is higher and insurance development has larger impact on developing countries. The insignificant effect of insurance development on g2 countries' economic growth is ambiguous. One quarter of g2 countries in this study are situated in Asia and Africa while half of them are from Europe and South America. As shown section 4.3, the positive effect of insurance development on economic growth is much significant if it is an Asian country or African country.

Dynamic model show that life insurance and nonlife insurance (except nonlife insurance penetration which is insignificant) promote economic growth in g2 countries but do not have effect on g1 countries. The development of insurance hurts economic growth in $\mathrm{g} 3$ countries. This implies that the time elements and process of change are important to study the effect of insurance development in g2 countries and g3 countries. Most of the g2 countries in are transition economies (transform from planned economy to market-based economy) such as countries from Central and Eastern Europe. Most of the g3 countries are victims Global Financial Crisis 2008 and European Debt Crisis 2009 such as United States and Western Europe countries which later adopt ultra-low interest rates. This model also shows that education enhance both insurance development and economic growth. For example, the state-run programs that improve financial literacy in Thailand and Philippines and increase demand for insurance which in turn maintains their domestic economy.

\subsection{Different initial income level of a country in different continent as a factor}

Despite section 4.1 shows that the Asian countries would amplify the positive effect of insurance development on economic, but that only applicable on $\mathrm{g} 1$ and $\mathrm{g} 2$ countries while g3 countries would experience similar effect like European countries. Japan is the most prominent example. Japan shares similar characteristics with certain European countries such as high debt to GDP ratio around $250 \%$ and prolonged ultra-low interest rate less than $1 \%$ since July 1995 and even negative interest rate since March 2016 because of the property bubble burst in late 1980s. Japan has the lowest FDI inflow among all the OECD countries due to lack of entrepreneurship and SMEs. Capital outflow happens because insurers intensify their oversea operation due to decline in revenues at home. Japan's economic situation has serious negative impacts on insurers' return and retrenchment happened. This further deteriorate the country's economic growth. Hence, it clearly illustrates that while insurance development may enhance economic growth, it still depends on the situation of the country's economy.

The results on European countries are consistent with previous results whereby g3 European countries mitigate the positive effect of insurance development on economic growth while g2 European countries amplify the effect. It is probably because most of the $\mathrm{g} 3$ countries in this study are members of Euro Zone such as Germany, France, Greece and Austria while g2 countries are not Euro Zone countries such as Ukraine, Poland, Hungary and Romania. Despite having imbalances between Euro Zone members such as unemployment and real borrowing cost, all members implement the same monetary policy set by ECB. In July 2007, the Greek 10-year sovereign bond has yield rate of $5.1 \%$ which is $0.2 \%$ higher than German 10 -year sovereign bond despite both countries have a very different inflation rate (German inflation rates are 1.9\%, $1.8 \%$ and 2.3\% for 2005, 2006 and 2007 respectively while Greek inflation rates are $3.5 \%, 3.3 \%$ and $3.0 \%$ ). Both countries basically have the same interest rate regardless of fundamentally different economic outlook. Euro Zone countries eventually tightly intertwined and sharing the same "fate" by sharing the same currency (Euro).

In South America, the results are also consistent with previous findings. There is mitigation of positive effect of insurance development on South American countries except one conflicting result. In the static model, the results show that insurance discourages economic growth in $\mathrm{g} 3$ countries in term of penetration but otherwise for density. There is no particular argument, a priori, to explain the conflicting results. In North America, the continent factor is more influencer than initial income factor in the effect of life insurance density development on g3 North American countries. g3 North American countries amplify the positive effect of life insurance density on economic growth as suggested in section 4.1 instead of mitigating the effect as suggested in section 4.2. The results are consistent with previous results which are g2 
North American countries amply the positive effect of insurance development while g3 north American countries mitigate it. For Africa, the results are consistent with the results in previous section. All African countries' insurance development enhances their economic growth.

\section{Discussion, Conclusion and Implications}

\subsection{Discussions of major findings}

This study finds significant causal relationship between insurance development and economic growth of a country. However, the strength and the nature (positive or negative) of the causality are varied in different situations such as initial income level of a country and its location. Some of the important results are the insurance development promotes economic growth of the countries in Asia and Africa significantly because of the huge untapped opportunities in Africa and promising and optimistic economic prospects in Asia. Conversely, insurance development generally hinders economic growth in South America countries. High-income countries such as Europe countries mitigate the positive effects of insurance development on their countries' economic growth because of their currency union while their non-member counterparts are able to reap the benefit of insurance development. Another major finding from the analysis is the effect of insurance development on economic growth of a country is indirect. The outcomes are dependent on the investment performance of insurers (especially life insurers). The investment performance in return depends on the economic prospects and economic policies of the country. Situation in Europe is more complicated because there is a currency union called Euro Zone that uses the same currency, namely Euro for their transactions. The analysis further suggests that the dominant way for insurance to contribute to economic growth is through their investment rather than encouraging the policyholders especially the ones whom are risk averse to bear riskier activity.

\subsection{Managerial implications}

This study implies that policymakers should consider the details of insurance investment despite that insurance development generally boosts a country's economy. Policymakers should clearly understand that insurance industry alone does not boost economic growth, but with the involvement of banking industry. The interconnectedness between Euro zone banking industry and insurance industry are very high. If banking industry faces trouble such as liquidity problem, it directly affects the operations of insurance industry and eventually slows down the economic growth. Should policymakers ignore the interconnectedness between insurance industry and banking industry, they would face the similar risk the failure of American International Group (AIG), a U.S. insurance company that is "too big to fail". European case also suggest that policymakers should not ignore the relationship between sovereign states and insurance industry. Policymakers should maintain their economy's stability for allowing insurance industry to catalyze the country's economic growth. Japan, United States, European countries and South American countries see their economic volatility like burst of economic bubbles, volatile exchange rates and high inflation affects the efficiency and return of insurance industry. In this case, the insurance industry would be a liability instead of an asset for economic growth. Lastly, it is always to be reminded that while some factors may be theoretically beneficial or detrimental to a country, its real effects are always dependent on each country's own special characteristics or regional characteristics (especially Euro Zone). Similarly, United States, Japan and Euro zone employ quantitative following a crisis, their outcomes are drastically different: Japanese's and Euro Zone's economies remain weak while United States regains its momentum.

\subsection{Limitations of the study \& recommendations for future research}

There are some limitations that needs to be addressed. Firstly, the use of difference GMM model as dynamic model for this study seems inappropriate due to insignificant results as compared to static models (either Fixed Effects Model or Random Effects Model). Additionally, the use of only 5 regions as a factor to study regional effect seems insufficient. However, these limitations do not detract from the significance of findings, but merely provide platforms for future research. Nevertheless, future research is recommended to use alternative dynamic models such as System GMM in studying similar study. This is because time elements such as feedbacks play a significant role in economic development and different dynamic models may be able to capture these crucial elements. Future study can also consider more regions and different categorizations of countries. For example, World Bank uses South Asia, Europe and 
Central Asia, Middle East and North Africa (MENA), East Asia and Pacific, Sub-Saharan Africa, North America and Latin America and Caribbean as their country groups. These regions could be more relevant for current economic situation. For example, the countries in Middle East and North Africa are mostly oil-producing countries and members of Organization of the Petroleum Exporting Countries (OPEC).

\section{Conclusion}

In conclusion, the effects of the insurance growth on economic growth on a country is very complicated. It depends on the unknown economic prospects of the country and the nature of insurers' investment performance which could be hard for policymakers to track. To make use of the insurance industry to boost their economic growth, policymakers have to investigate all economic agents thoroughly because there might be a link between them and insurers. To sum it all up, insurance industry can be an asset for an economy, but it can also be a liability to an economy.

\section{References}

1. Alhassan AL, Biekpe N. Insurance market development and economic growth. International Journal of Social Economics, 2016, 43(3): 321-339.

2. Arena M. Does insurance market activity promote economic growth? A cross-country study for industrialized and developing countries. Journal of Risk \& Insurance, 2008, 75(4): 921-946.

3. Azman-Saini W, Smith P. Finance and growth: New evidence on the role of insurance. South African Journal of Economics, 2011, 79(2): 111-127.

4. Bank EC. Official interest rates. http://www.ecb.europa.eu/stats/policy_and_exchange_rates/key_ecb_interest_rates/html/index.en.html

5. Bloomberg I. How to fix the Euro area without breaking it Bloomberg professional services. https://www.bloomberg.com/professional/blog/how-to-fix-the-euro-area without-breaking-it/

6. Christopher BF. Residual diagnostics for cross-section time series regression models. The Stata Journal, 2001, 101-104.

7. Chen P, Lee C, Lee C. How does the development of the life insurance market affect economic growth? Some international evidence. Journal of International Development, 2011, 24(7): 865-893.

8. Ching KS, Kogid M, Furuoka F. Causal relation between life insurance funds and economic growth evidence from Malaysia. ASEAN Economic Bulletin, 2010, 27(2): 185.

9. Chi Wei S, Hsu Ling C, Guochen P. Tests for causality between insurance development and economic growth using asymptotic and panel bootstrap distributions. Journal of Economic Literature.

10. Concha A, Taborda R. Insurance use and economic growth in Latin America. Some panel data evidence. Lecturas de Economía, 2014, (81).

11. Declaration of human entrepreneurship in Jakarta, Indonesia. http://www.icsb.org/wp-content/uploads/2015/09/ForRelease-ICSB-JakartaDeclaration HumanEntrepreneurship.pdf

12. Enz R. The S-Curve relation between per-capita income and insurance penetration. Geneva Papers on Risk and Insurance - Issues and Practice, 2000, 25(3): 396-406.

13. Eurostat HICP-inflation rate. http://ec.europa.eu/eurostat/tgm/table.do?tab=table\&init=1\&language=en\&pcode=tec00118\&plugin=1

14. Evans-Pritchard A. Olivier Blanchard eyes ugly 'end game' for Japan on debt spiral. http://www.telegraph.co.uk/business/2016/04/11/olivier-blanchard-eyes-ugly-end-game-for-japan-on-debt-spiral/

15. Gregor E, Dr. Michaela G. Insurance markets in Asia - quality before growth.

https://www.allianz.com/v_1436877013000/media/economic_research/publications/working_papers/en/Asien2015 e.pdf

16. Haiss P, Sümegi K. The relationship between insurance and economic growth in Europe: A theoretical and empirical analysis. Empirica, 2008, 35(4): 405-431.

17. Han L, Li D, Moshirian F, et al. Insurance development and economic growth. The Geneva Papers on Risk and Insurance - Issues and Practice, 2010, 35(2): 183-199.

18. Horng M, Chang Y, Wu T. Does insurance demand or financial development promote economic growth? Evidence from Taiwan. AppliedEconomics Letters, 2012, 19(2): 105-111.

19. Hou H, Cheng S, Yu C. Life Insurance and Euro Zone's Economic Growth. Procedia - Social and Behavioral Sciences, 2012, 57: 126-131.

20. IMF DataMapper. http://www.imf.org/external/datamapper/NGDP_RPCH@WEO/OEMDC/ADVEC/WEOWORLD/SMQ

21. Insurance opportunities in Latin America. 
http://www.ey.com/Publication/vwLUAssets/ey-insurance-opportunities-in-latin-america/\$FILE/ey-insurance-opp ortunities-in-latin-america.pdf

22. International Monetary Fund. Germany financial sector assessment program stress testing the banking and insurance sector - Technical note. https://www.imf.org/external/pubs/ft/scr/2016/cr16191.pdf

23. Kirk A. European debt crisis: It's not just Greece that's drowning in debt. http://www.telegraph.co.uk/news/0/european-debt-crisis-not-just-greece-drowning-debt/

24. Lee $\mathrm{C}$, Lee $\mathrm{C}$, Chiu Y. The link between life insurance activities and economic growth: Some new evidence. Journal of International Money and Finance, 2013, 32: 405-427.

25. Life insurance markets in Sub-Saharan Africa. http://www.prudential.co.uk/ /media/Files/P/Prudential-V2/content-pdf/odi-paper-insurance-marketsfinal.pdf

26. Lu C, Yanagihara M. Life insurance, human capital accumulation and economic growth. Australian Economic Papers, 2013, 52(1): 52-60.

27. Luis LM. The Spanish banking system: Situation and challenges. http://www.bde.es/f/webbde/GAP/Secciones/SalaPrensa/IntervencionesPublicas/Gobernador/Arc/Fic/Linde180716 en.pdf

28. M. The three big issues facing Latin America. https://www.weforum.org/agenda/2014/03/three-bigissues-facing-latin-america/

29. Mehreen K. Greek bank deposit outflows hit $€ 1$ bn in February. https://www.ft.com/content/4e178abc-3ba6-30c8-8fdc-d3cd35cc4c88

30. Moody's maintains stable outlook on Portugal's banking system amid modest economic recovery. https://www.moodys.com/research/Moodys-maintains-stable-outlook-on-Portugals-banking-system-amid-modest-PR_357271

31. Morris S. Profit replaces risk as big worry among Europe bank regulators. https://www.bloomberg.com/news/articles/2016-12-16/sagging-bank-profits-replace-capital-as-eu-regulators-bigworry

32. Nicholas CJ. Transformations: An introduction. http://fmwww.bc.edu/repec/bocode/t/transint.html

33. Nyholm K. Insurance and banking interconnectedness in Europe: The opinion of equity markets. Economics Research International, 2012, 1-8.

34. OECD economic surveys JAPAN. http://www.oecd.org/eco/surveys/Japan-2015- overview.pdf

35. Oliver A, Guglielmo R, Philipp W. Cloudy sky over Italian banks. https://www.creditsuisse.com/us/en/articles/articles/news-and-expertise/2016/08/en/cloudy-sky-over-italian-banks.html

36. Ongoing change in Japan's life insurance industry. https://www.jetro.go.jp/ext_images/en/reports/market/pdf/2005_48_m.pdf

37. Outreville JF. The economic significance of insurance markets in developing countries. The Journal of Risk and Insurance, 1990, 57(3): 487.

38. Partington R. European banks stuck with $\$ 1.3$ trillion of bad loans, KPMG says. https://www.bloomberg.com/news/articles/2016-10-31/european-banks-stuck-with-1-3-trillion-of-bad-loans-kpmg -says

39. Pradhan RP, Arvin MB, Norman NR. Insurance development and the finance-growth nexus: Evidence from 34 OECD countries. Journal of Multinational Financial Management, 2015, 31: 1-22.

40. PwC. InsurTech: A golden opportunity for insurers to innovate. https://www.pwc.com/us/en/insurance/publications/assets/pwc-top-issues-insurtech.pdf

41. Schuetze JS, Kröner A. Exclusive: Deutsche bank to sell \$1 billion of shipping debt to boost capital - sources. http://www.reuters.com/article/us-deutsche-bank-loans-shipping-exclusiv-idUSKCN0ZM19I

42. Shauna F. Repercussions: The impact of the AIG Bailout on its insurance subsidiaries. http://www.actuaries.asn.au/Library/Events/SUM/2013/FerrisAIGProducts.pdf

43. Situation and economic indicators of SMEs in 2015. http://www.sme.go.th/eng/images/data/SR/download/2015/report_year/ExecutiveSummary/Chapter\%201.pdf

44. The role of insurance in Latin America. https://www.zurich.com/_/media/dbe/corporate/docs/corporate-responsibility/insurance-latin-america-en.pdf?la=fr ca\&hash=1730438CDDC̄3C0F064A92DBC5DF24DDD0F0737EC

45. Ward D, Zurbruegg R. Does insurance promote economic growth? Evidence from OECD countries. The Journal of Risk and Insurance, 2000, 67(4): 489.

46. 2016 EY Asia-Pacific insurance outlook. http://www.ey.com/Publication/vwLUAssets/EY-asiapac-insurance-outlook-2016/\$FILE/EY-asiapac-insurance-out look-2016.pdf

47. 2016 EY Latin America insurance outlook. http://www.ey.com/Publication/vwLUAssets/EY-2016-latin-america-insurance-outlook/\$FILE/EY-2016-latin-amer ica-insurance-outlook.pdf 
48. 2017 Asia-Pacific insurance outlook. http://www.ey.com/Publication/vwLUAssets/ey2017-asia-pacific-insurance-outlook/\$FILE/ey-2017-asia-pacific-insurance-outlook.pdf 